\author{
JOANNA JĘDRZEJEWSKA-SZMEK ${ }^{1}$, DANIEL K. WÓJCIK ${ }^{1,2}$ \\ ${ }^{1}$ Pracownia Neuroinformatyki \\ Instytut Biologii Doświadczalnej im. M. Nenckiego PAN \\ Pasteura 3, 02-093 Warszawa \\ 2Instytut Psychologii Stosowanej \\ Wydział Zarzadzania i Komunikacji Społecznej \\ Uniwersytet Jagielloński \\ Łojasiewicza 4, 30-348 Kraków \\ E-mail:d.wojcik@nencki.edu.pl
}

\title{
OBLICZA NEUROINFORMATYKI
}

\section{WSTEP}

Neuroinformatyka to stosunkowo nowa nauka. Samo słowo pojawiło się w latach 80. XX w. w Stanach Zjednoczonych, gdzie tak właśnie zaczęto określać rozwój baz danych i narzędzi komputerowych w celu wsparcia badań nad mózgiem. W Polsce przyjęliśmy szersze znaczenie neuroinformatyki, obejmujace wszelkie zastosowania nauk ścisłych w neurobiologii, w tym neurobiologie teoretyczną, obliczeniowa, analize sygnałów neurobiologicznych, rozwój wszelkich metod analizy danych uzyskanych w ramach badań mózgu i behawioru bez względu na modalność, danych elektrofizjologicznych, obrazowania, behawioralnych oraz zastosowanie tych metod do analizy danych doświadczalnych. $Z$ jednej strony naturalne byłoby traktowanie tej aktywności jako części bioinformatyki, której nazwa sugeruje zastosowanie informatyki w biologii. Jednak historyczna identyfikacja bioinformatyki $z$ biologia molekularna i genetyka spowodowały, że badacze stosujący nauki ścisłe w kontekście badań mózgu na wielu poziomach potrzebowali nowej nazwy, dziedziny, z którą mogliby się identyfikować.

Rozwój neuroinformatyki, jako tak szeroko rozumianej dziedziny, jest konsekwencją kilku trendów obecnych we współczesnej nauce, $z$ których tylko niektóre sa specyficzne dla badań nad mózgiem. Dzięki systematycznemu rozwojowi technik pomiarowych, rosnacej liczbie typów pomiarów i ich precyzji, nasza wiedza o wszelkich aspektach anatomii i funkcjonowania mózgu przyrasta coraz szybciej. Żeby ją optymalnie wykorzystać i połączyć w spójny obraz anatomii i funkcji układu nerwowego, niezbędne sa odpowiednie narzędzia komputerowe do integracji danych, syntetyczne teorie oraz coraz bardziej zaawansowane metody analizy danych (Ryc. 1).

Równolegle do rozwoju technik pomiarowych w biologii, przyspiesza rozwój komputerów i technologii informacyjnych, pozwalających na przechowywanie i przetwarzanie danych zebranych za pomoca tych nowoczesnych metod rejestracji, oraz konstruowanie postulowanych przez teoretyków modeli obliczeniowych o rosnącej złożoności. Wśród głównych przeszkód stojących na drodze rozwoju neuroinformatyki, czy szerzej, zastosowań matematyki i nauk ścisłych w biologii, należy wskazać tradycyjna separację tych dziedzin na uniwersytetach, mimo historycznie wielu wspólnych wątków w rozwoju fizyki i fizjologii. Ten rozdział wydaje się szczególnie niefortunny dzisiaj, kiedy gwałtownie rosną szansę na współpracę między tymi dziedzinami (BIALEK i BOTSTEIN 2004, COHEN 2004). W odpowiedzi na rosnace zapotrzebowanie na badaczy pracujacych na styku nauk ścisłych i neurobiologii, w wielu krajach stworzono specjalne programy badawcze promujace rozwój neuroinformatyki.

Ostatnia dekada XX w., ogłoszona w USA dekadą mózgu (ang. Decade of the Brain, 1990-1999), silnie wzmocniła tę dziedzinę. $\mathrm{Na}$ początku lat 90. XX w. kil- 


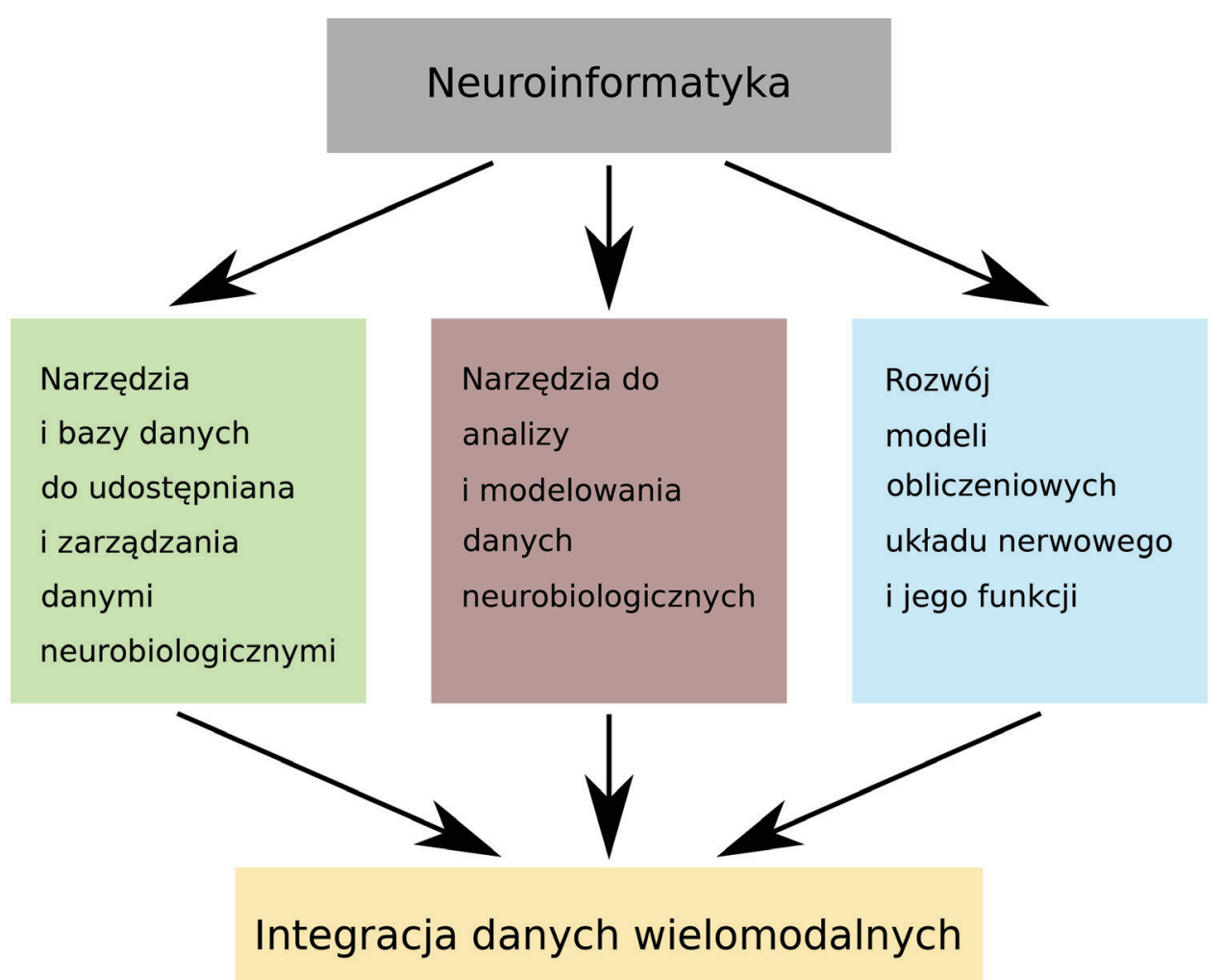

Ryc. 1. Oblicza neuroinformatyki.

ka amerykańskich agend rządowych zleciło Instytutowi Medycyny Narodowej Akademii Nauk USA (ang. National Institutes of Health; NIH) zbadanie zapotrzebowania na ogólnodostępne bazy danych neurobiologicznych oraz zbadanie możliwości informatyki $\mathrm{w}$ zakresie tworzenia narzędzi niezbędnych do przetwarzania rosnacej liczby danych pozyskiwanych $\mathrm{w}$ badaniach mózgu. W konsekwencji pozytywnej rekomendacji (PECHURA i MARTIN 1991), amerykański National Institute of Mental Health (NIMH) opracował amerykański program Human Brain Project, w ramach którego w ciagu 10 lat (19932004) zainwestowano ok. $100 \mathrm{mln}$ dolarów $\mathrm{w}$ pierwsze, znaczace projekty neuroinformatyczne, w szczególności stworzenie szeregu baz danych i portali. Wiele $z$ tych narzędzi i repozytoriów jest obecnie udostępniane publicznie poprzez the Neuroscience Information Framework (NIF) (http://www.neuinfo. org/).

Pod koniec XX w. w ramach inicjatywy Mega Science Forum, a następnie Global Science Forum, kraje OECD uznały konieczność udzielenia wsparcia neuroinformatyce na świecie i w 2007 r. utworzyły International Neuroinformatics Coordinating Facility (INCF), organizacje koordynująca rozwój neuroinformatyki na świecie. Równolegle, w 2004 r. Niemcy uruchomiły Sieć Bernsteina, inicjatywę, w ramach której na drodze krajowych konkursów finansowano badania w dziedzinie neuroinformatyki przez dziesięć lat, przede wszystkim neurobiologię obliczeniową i teoretyczna, co ugruntowało pozycję Niemiec jako jednego ze światowych liderów w tej dziedzinie. W 2013 r. europejski projekt naukowy the Human Brain Project (HBP) wygrał konkurs agencji Future and Emerging Technologies (FET) H2O2O i został sfinansowany przez Komisje Europejska, jako jeden $z$ dwóch flagowych projektów FET. W tym samym roku Stany Zjednoczone uruchomily Brain Initiative, program częśsiowo równoległy, a częściowo komplementarny do HBP. Także w Chinach, Japonii, Australii i innych krajach uruchomiono dedykowane programy wspierajace badania mózgu, z których większość silnie wzmacnia także rozwój neuroinformatyki.

W Polsce neuroinformatyka obecna jest od kilku dekad. Wydział Fizyki Uniwersytetu Warszawskiego prowadzi specjalność Neuroinformatyka na poziomie studiów I i II stopnia, a w kraju działa kilka grup prowadzacych badania neuroinformatyczne. Rozwijana jest zarówno infrastruktura - bazy danych, np. repozytoria atlasów mózgów (https://3dbars.org), połączeń w mózgu naczelnych (https://marmosetbrain.org), metody i narzędzia analizy danych elektrofizjologicznych, obrazowych i behawioralnych, a także modele układu nerwowego. Znacząca działal- 
nością jest rozwój metodologii na potrzeby badań poznawczych i klinicznych ludzi, w kontekście interfejsów mózg-komputer, a także neuroinżynierii.

Chociaż wszystkie aspekty neuroinformatyki są warte omówienia, w dalszym ciagu tego artykułu skupimy się na jednym tylko nurcie, mianowicie neurobiologii obliczeniowej. W jej ramach omówimy biofizycznie realistyczne modelowanie układu nerwowego oraz przyjrzymy się dokładniej współczesnym modelom plastyczności synaptycznej.

\section{MODELOWANIE REALISTYCZNE BIOFIZYCZNIE}

Chociaż biologia jest dzisiaj postrzegana przede wszystkim jako nauka doświadczalna, tak jak w przypadku każdej innej nauki, modelowanie jest jej istotna częścią. Model stanowi pewien zestaw pojęć i aksjomatów, do których odnosimy się w celu wyjaśnienia badanego zjawiska. Nawet jeżeli jest to model jakościowy i nie deklarujemy go explicite, każde wyjaśnienie zjawiska biologicznego funkcjonować będzie wyłącznie w jego ramach, bo $z$ natury rzeczy, opisujacc dowolne zjawisko, obiekt czy proces, zmuszeni jesteśmy zawęzić nasze pole widzenia do fragmentu poznanej rzeczywistości.

Od czasów Newtona siła nauk ścisłych jest wykorzystywanie modeli ilościowych, czyli opisywanych równaniami, które określają związki między poszczególnymi wielkościami. Ich przewaga nad modelami jakościowymi polega na tym, że precyzyjniej opisuja badane zjawiska i pozwalaja na dokładniejsze i łatwiej falsyfikowalne predykcje niż modele jakościowe. Niestety, modele ilościowe przyjmuja się wolniej w biologii niż w fizyce czy chemii, co częściowo wiąże się $z$ większą złożonościa zjawisk biologicznych. Tym niemniej, próby ilościowego opisu zjawisk zachodzacych w mózgu prowadzone były praktycznie równolegle do badań doświadczalnych. Zjawiska elektryczne zachodzace w mięśniach, badane przez G. Galvaniego i A. Voltę na przełomie XVIII i XIX w., stanowiły istotny wkład zarówno do rozwoju teorii elektryczności, jak i elektrofizjologii. Teorię propagacji sygnału elektrycznego w kablu dendrytycznym zaczęli rozwijać H. Weber, M. Cremer i L. Hermann pod koniec XIX w., w oparciu o teorię podwodnych kabli telegraficznych opracowana przez Williama Thomsona (Lorda Kelvina) w połowie XIX w. (JACK i współaut. 1975). W szczególności Hermann zwrócił uwagę, że teoria kabla może wystarczyć do opisu propagacji potencjału czynnościowego, impulsu elektrycznego generowanego w aksonie, zwanego również iglica. W latach 30. XX w. teoria przewodnictwa sygnału, oparta o teorię kabla, zaczęła gwałtownie się rozwijać w zwiazku z licznymi doświadczeniami, które w szczególności wskazywały na jej znaczenie $\mathrm{w}$ opisie propagacji iglicy $\mathrm{w}$ aksonie (m.in. Cole, Curtis, Hodgkin, Rushton, Lorente de No, Katz i wspólpracownicy; patrz JACK i współaut. 1975). W latach 50. XX w. systematyczny rozwój technik pomiarowych pozwolił na badanie własności elektrycznych drzewa dendrytycznego. W zagadnieniu tym teoria kabla odegrała kluczowa rolę w interpretacji otrzymywanych wyników doświadczalnych. Prace teoretyczne nad rozwojem tej teorii dla złożonych drzew dendrytycznych prowadzili m.in. W. Rall, J. Rinzel, W. Tuckwell, I. Segev, i inni (prace przeglacdowe: JACK i współaut. 1975, TUCKWELL 1988, JOHNSTON i WU 1995, KOCH 1999).

W ujęciu fizycznym teorię kabla wyprowadza się przy założeniu reprezentacji błony komórki nerwowej jako układu elektrycznego. Przyjmujemy, że część lipidowa błony jest nieprzepuszczalna dla jonów i zachowuje się jak kondensator, czyli przy różnicy potencjału elektrycznego po obu stronach błony, na jej powierzchni gromadza się jony przeciwnie naładowane. $Z$ kolei kanały jonowe zapewniajace przepływ jonów między wnętrzem komórki a przestrzenia zewnątrzkomórkowa określaja opór błony komórkowej. Ponieważ jony napływajace do komórki przez błonę w danym punkcie moga przepływać do innych obszarów komórki, równanie kabla otrzymujemy stosujac prawa Ohma dla obwodów elektrycznych.

Poczatkowo teoria kabla zakładała stały opór błony neuronów (bierne kable), z czasem uwzględniono fakt, że w błonie komórkowej drzewa dendrytycznego znajdują się aktywne kanały jonowe, których oporność zależy od napięcia elektrycznego po obu stronach błony, albo od przebiegu pewnych procesów biochemicznych. Obecnie stosowane symulatory aktywności neuronów i sieci neuronowych, takie jak NEURON, Genesis, czy Moose, pozwalaja na uwzględnienie tego typu zjawisk w modelach komórek o złożonym dendrytycznym drzewie. W szczególności, możliwe jest wykorzystanie morfologii neuronów zrekonstruowanych $z$ obrazów mikroskopowych.

Teoria kabla pozwoliła na opis zachowania biernych dendrytów i propagacji sygnałów elektrycznych w kablu dendrytycznym, ale nie pozwoliła na wyjaśnienie mechanizmu generacji potencjału czynnościowego. Dopiero A. Hodgkin i A. Huxley w kilku pracach zbadali własności kanałów sodowych i potasowych odpowiedzialnych za generację iglicy i zaproponowali jakościowy i ilościowy fizyczny model ich funkcjonowania, 
przy użyciu abstrakcyjnych „bramek”, czyli funkcji aktywacji i inaktywacji kanałów jonowych (HODGKIN i HUXLEY 1952). Wykorzystujac swój model przeprowadzili symulację komputerowa, otrzymujac przebieg potencjału czynnościowego na błonie komórki zgodny $z$ rejestracjami doświadczalnymi. Dopiero późniejsze badania strukturalne pokazały, że bramki zapostulowane przez Hodgkina i Huxleya istnieja w rzeczywistości. Sa nimi podjednostki kanałów jonowych, a sugerowana dynamika bramek odzwierciedla zmiany konformacji białek pod wpływem czynników zewnętrznych (w tym przypadku: zmiany pola elektrycznego na błonie komórkowej).

Wyjaśnienie mechanizmu generacji potencjału czynnościowego było przełomem w neurobiologii, bo wcześniejsze teorie były niezgodne $z$ dobrze potwierdzona teoria kabla, i ustanowiło kamień węgielny neurobiologii obliczeniowej. Od tamtej pory w praktyce modelowania wszystkie nowe nieliniowe mechanizmy odkryte doświadczalnie starano się opisać przy użyciu formalizmu zaproponowanego przez Hodgkina i Huxleya. W połączeniu $z$ teorią kabla dla złożonych drzew dendrytycznych i modelami transmisji synaptycznej stworzono, wykorzystywane do dzisiaj, podejście pozwalające na realistyczne modelowanie potencjalnie dowolnie złożonych sieci komórek nerwowych.

Podstawowe przeszkody utrudniajace wykorzystanie modeli do lepszego zrozumienia układu nerwowego, to przede wszystkim brak dostępnych odpowiednich danych doswiadczalnych i zawsze zbyt słaba moc obliczeniowa. Dlatego wczesne modele komórek nerwowych i nieskomplikowanych sieci były silnie uproszczone; wykorzystywały dane pozyskane $z$ różnych modeli zwierzęcych przy różnych paradygmatach doświadczalnych, np.: morfologię komórki szczurzej, własności jednych kanałów $z$ komórek mysich, a innych ze świnki morskiej. W ostatnich latach znaczaco zmienił się paradygmat obliczeniowy. Jako społeczność naukowa zdaliśmy sobie sprawę, że tradycyjne podejście do badania układu nerwowego, gdzie poszczególni badacze badaja nieduże grupy komórek, czy pojedyncze struktury, używając nieznacznie różniących się od siebie paradygmatów doświadczalnych, utrudnia integrację danych i tworzenie syntetycznych teorii wyjaśniajacych podstawy zjawisk neurobiologicznych. Ta obserwacja była inspiracja do uruchomienia kilku ciekawych inicjatyw. W ramach projektu Mindscope w Instytucie Badań Mózgu Allena (ang. Allen Institute) w Seattle, systematycznie rejestrowane sa kolejne komórki w korze mysiej, według takiego samego protokołu, po czym ich morfologie, a także modele ich aktywności elektrycz- nej, które moga być od razu wykorzystane w symulacjach, sa publicznie udostępniane. Podobna filozofia przyświeca badaniom prowadzonym w ramach europejskiego Human Brain Project i jego części skupiającej się na badaniach teoretycznych, która wyrosła ze szwajcarskiego Blue Brain Project. Paradoksalnie, finansowany ze środków publicznych HBP udostepnia dane w znacznie bardziej złożony sposób i $z$ większymi ograniczeniami niż prywatny Allen Institute. Obecna praktyka badawcza w tych dużych projektach daje nadzieję na zebranie danych pozwalajacych na pełen opis ilościowy i konstrukcję modeli, przynajmniej wybranych struktur (kora nowa, hipokamp) oraz modeli mózgów wybranych pojedynczych gatunków zwierząt, przybliżając powstanie teorii syntetycznych.

Moc obliczeniowa dostepnych komputerów od lat systematycznie rośnie, pozwalajac od niedawna na budowanie modeli sieci neuronalnych w skali porównywalnej $z$ rzeczywistym układem nerwowym. Oznacza to, że albo liczba komórek w modelu jest porównywalna $z$ liczba komórek w mózgu myszy (chociaż komórki modelu sa uproszczone - punktowe, bez morfologii), albo komórki maja realistyczne morfologie, ale ich liczba $\mathrm{w}$ danym modelu odpowiada pojedynczej kolumnie korowej (Blue Brain Project). Nie ma wątpliwości, że w najbliższej przyszłości, w skali rzędu 10-20 lat, będziemy w stanie modelować układy komórek nerwowych porównywalne $z$ mózgami modeli zwierzęcych, być może nawet człowieka. Tu oczywiście należy zwrócić uwage na to, że najpoważniejsza przeszkodą pozostaje wciąz dostęp do danych doświadczalnych, bo własności komórek ludzkich, ze względów praktycznych i etycznych, poznajemy głownie $z$ materiału pobranego od pacjentów chorych na nowotwory czy epilepsje lub badajac ich aktywność w trakcie operacji neurochirurgicznych lub poza organizmem (np. QUIROGA i współaut. 2005, KAMIŃSKI i współaut. 2017).

Odpowiednie możliwości techniczne i nawet wystarczajaco bogate zestawy danych nie gwarantuja niestety, że nasze modele poprawnie wyjaśnia rzeczywiste działanie mózgu. Wiele dziedzin neuronauki wymaga dalszych, intensywnych badań; dotyczy to zarówno nowych koncepcji, rejestracji brakujacych danych, jak i poziomu modelowania. Na przykład nie wyjaśniono jeszcze dokładnie wpływu gleju na przetwarzanie informacji w układzie nerwowym. Wiadomo, że interakcje komórek nerwowych $z$ glejem, zwłaszcza astrocytami, maja wpływ na wynik obliczeń wykonywanych przez komórki nerwowe $i$ w konsekwencji, na ich aktywność (HALNES i współaut. 2013, OsCHMANN 
i współaut. 2018), ale efekty tych interakcji nie sa jeszcze szczegółowo zbadane.

Punktem spornym jest również sensowność podejścia ultrarealistycznego, którego celem jest maksymalnie wierna reprezentacja rzeczywistości w modelach mózgu. Samo przedstawienie układu nerwowego w postaci układu równań opisującego każdy, nawet najmniejszy detal, niekonieczne przybliży zrozumienie jego funkcjonowania. Dlatego równolegle, w neurobiologii obliczeniowej prowadzi się wiele innych strategii badań, rozwijając modele uproszczone, w których rezygnuje się $z$ morfologii komórki, albo upraszczając równania opisujące generację potencjału czynnościowego (GERSTNER i współaut. 2014). Można też zastępować aktywność populacji komórek ich średnią aktywnością. Podejście to przypomina praktyke fizyki statystycznej i prowadzi do konstrukcji modeli polowych (ang. mean-field models) (np. WILson i CoWAN 1972), które sa szczególnie odpowiednie do modelowania aktywności zbiorczej mózgu, modelowania fal mózgowych i odniesienia do wielkoskalowych rejestracji typu EEG, MEG czy fMRI. Dla modeli tych pojawia się problem modelowania pomiaru, bo przejście od aktywności komórek do tego, co mierzymy zależy od typu pomiaru, czasami w złożony sposób, ale to już zupełnie inna historia (DENKER i współaut. 2014).

Nie mamy wątpliwości, że złożoność układu nerwowego będzie angażować i inspirować zarówno eksperymentatorów, jak $\mathrm{i}$ teoretyków przez jeszcze wiele lat. Tematem, który jest teraz szczególnie intensywnie badany, jest plastyczność w układzie nerwowym, zjawisko, które wiąże się $z$ jedną $Z$ podstawowych funkcji mózgu - uczeniem się i pamięcią. Poza aspektami poznawczymi, chcemy zrozumieć plastyczność również w kontekście klinicznym, bo wiele chorób neurodegeneracyjnych wiąże się $z$ zaburzeniami pamięci. Mamy także nadzieję, że lepsze zrozumienie procesów plastycznych w mózgu pozwoli na rozwój nowych algorytmów uczacych, które pozwola maszynom coraz lepiej naśladować w tym względzie człowieka, co ma fundamentalne znaczenie praktyczne. Trzecia fala rozwoju technik sztucznych sieci neuronowych, która gwałtownie rozwija się od kilku lat pod nazwa głębokiego uczenia (GoOdFEllow i współaut. 2016), przyniosła znaczacca poprawę wyników maszynowych rozwiazań wielu problemów dotychczas trudnych dla maszyn, chociaż łatwych dla ludzi, jak np. komputerowe widzenie, przetwarzanie mowy, rozpoznawanie znaczenia w języku naturalnym, itp. Spekuluje się, że inteligentne właczenie biologicznie inspirowanych mechanizmów plastyczności może te wyniki jeszcze znaczaco poprawić.

\section{MODELOWANIE PLASTYCZNOŚCI}

W procesie zwanym plastycznościa waga synapsy (połaczenia między komórkami nerwowymi) ulega zmianom. Dzieje się to najczęściej pod wpływem aktywności danej komórki i połaczonych $z$ nią neuronów. Począwszy od prac KonoRsKiEgo (1948) i HEBBA (1949) uważa się, że długotrwała plastyczność synaptyczna, w szczególności ta trwajaca przez co najmniej kilka godzin i wymagająca syntezy nowych związków chemicznych, jest molekularnym procesem odpowiedzialnym za uczenie i formowanie się pamięci - zdolności sieci neuronalnej do reorganizacji w wyniku poprzednich doświadczeń (MALENKA i BeAR 2004). Plastyczność o krótszej skali czasowej, trwająca od kilkunastu milisekund do kilku sekund, jest podstawa dla dynamicznych zmian przetwarzania informacji, w tym adaptacji. Gdy waga synapsy (średni potencjał postsynaptyczny albo postsynaptyczne natężenie pradu generowane $\mathrm{w}$ odpowiedzi na potencjał czynnościowy komórki presynaptycznej) zwiększa się, mówimy o wzmocnieniu lub facylitacji, co odpowiada zapamiętywaniu, gdy waga synapsy zmniejsza się mówimy o osłabieniu, co odpowiada zapominaniu (NABAVI i współaut. 2014). Wzmocnienie i osłabienie synaptyczne moga występować w tych samych połaczeniach, co nazywamy plastycznościa dwukierunkowa.

Mianem plastyczności synaptycznej określa się zróżnicowana grupę procesów, które sa wywoływane przez różne mechanizmy biologiczne, zależą od obszaru mózgu, typu połaczeń i sposobu wywoływania, a charakteryzuje je różny czas trwania i amplituda. Dlatego ogólny opis i zrozumienie tego zjawiska sa niezwykle trudne, a modele opisujace plastyczność w wybranym obszarze mózgu nie będa dobrze odzwierciedlały plastyczności występujacej gdzie indziej. W warunkach doświadczalnych plastyczność synaptyczna wywołuje się zwykle przez stymulację elektryczną wywołująca serię potencjałów czynnościowych o pewnej częstości (tetanizacja) w szlaku neuronalnym, powodujac w jego obrębie wzrost albo spadek wagi połączeń synaptycznych.

Modele plastyczności synaptycznej najczęściej dzieli się na fenomenologiczne i biofizyczne. Modele fenomenologiczne nie skupiają się na mechanizmach biofizycznych bądź biochemicznych, lecz staraja się odzwierciedlić działanie systemu, traktujac go jako tak zwana "czarna skrzynkę". Aktywność neuronów, które łączy synapsa: presynaptycznego, który wysyła sygnał, i postsynaptycznego, który odbiera sygnał, bądź częstość ich aktywacji, stanowi wejście do czar- 
nej skrzynki - synapsy. Wyjściem z czarnej skrzynki jest waga synapsy bądź jej zmiana. Modele fenomenologiczne sa prostsze koncepcyjnie i mniej złożone obliczeniowo niż modele biofizyczne, dzięki czemu sa wygodnym narzędziem w symulacjach sieci neuronowych i analizach matematycznych. Używa się ich w badaniach teoretycznych majacych na celu zrozumienie tego, jak przebiega proces uczenia.

Jednym $z$ pierwszych i najbardziej interesujących modeli opartych na częstości aktywacji neuronów jest model BCM, Bienenstocka, Coopera i Munro (BIENESTOCK i współaut. 1982). Teoria BCM tłumaczy m.in. powstawanie kolumn orientacji bodźca w korze wzrokowej. U zdrowych zwierzat neurony tworzace kolumny orientacji sa obuoczne i wybiórczo reaguja na określone nachylenia krawędzi bodźca wzrokowego (HUBEL i WIESEL 1962) (selektywność na pewna wybiórczą klasę bodźca jest typową własnością neuronów kory zmysłowej). Kolumny orientacji bodźca wzrokowego wykształcaja się podczas obfitej synaptogenezy i pruningu, w okresie krytycznym. W modelu BCM zmiana wagi synapsy jest wprost proporcjonalna do aktywności neuronu presynaptycznego (wejściowego) i pewnej, niemonotonicznej funkcji zależnej od poprzedniej („historycznej") aktywności neuronu postsynaptycznego (wyjściowego). Pozwala to zarówno na wiążace się $z$ długotrwałym osłabieniem synaptycznym (ang. long-term depression, LTD) obniżenie wagi synapsy, jak i wiążące się $z$ długotrwałym wzmocnieniem synaptycznym (ang. long-term potentiation, LTP) jej zwiększenie. Wzmocnienie i osłabienie synaptyczne rozdzielone sa ruchomym progiem zależnym od poprzedniej polaryzacji neuronu postsynaptycznego. Teoria BCM jest niezwykle wszechstronna i opisuje zarówno kształtowanie się wybiórczej reakcji na określone nachylenia bodźca wzrokowego (BLAIS i współaut. 2000), różne stopnie dominacji ocznej (SHOUVAL i współaut. 1996) czy efekty doświadczeń $z$ deprywacją wzrokowa i niektóre aspekty plastyczności homeostatycznej (YEUNG i współaut. 2004), takie jak skalowanie synaptyczne. W procesie tym w odpowiedzi na podwyższona aktywność neuronalna, żeby ustabilizować zakres dynamiki neuronu, wagi wszystkich synaps danego neuronu zostaja pomnożone przez ten sam czynnik, tak że względny rozkład wag synaps jest zachowany (TURRIGANO 1999)

W latach 90. XX w. rozpoczęto prace nad modelem zjawiska plastyczności zależnej od synchronizacji aktywacji neuronów pre- i postsynaptycznego (ang. spike-timing dependent plasticity, STDP) (m.in. MARKRAM i współaut. 1997, BI i POO 1998). STDP wy- wołuje się przez dwie stymulacje oddzielone pewnym interwałem czasowym (ang. inter-stimulus interval, ISI): 1) neuronu presynaptycznego, wywołujacc potencjał czynnościowy i w konsekwencji transfer synaptyczny, 2) postsynaptycznego, wywołujac propagujący się wstecznie po drzewie dendrytycznym potencjał czynnościowy. Tak sparowany bodziec, składajacy się ze stymulacji presynaptycznej i postsynaptycznej, powtarza się zwykle od pięćdziesięciu do stu razy (aczkolwiek w przypadku neuronów prażkowia już kilka powtórzeń wystarczy do wzmocnienia synapsy) (CUI i współaut. 2016). Klasyczna postać STDP jest asymetryczna i spełnia hebbowska zasadę kojarzenia, co oznacza, że jeżeli komórka presynaptyczna jest aktywowana przed komórka postsynaptyczną, następuje wzmocnienie synapsy, natomiast jeżeli komórka postsynaptyczna jest aktywowana jako pierwsza, następuje osłabienie połączenia. Gdy interwał czasowy pomiędzy stymulacja pre- i postsynaptyczną jest większy od kilkudziesięciu milisekund, waga synapsy nie zmienia się. W szczególności modele STDP opierajace się na wykrywaniu koincydencji między stymulacja pre- i postsynaptyczna pokazały, że w sieciach neuronalnych $z$ połaczeniami wykazujacymi STDP moga wykształcić pola recepcyjne (CLOPATH i współaut. 2010).

W procesach plastycznych ośrodkowego układu nerwowego niezwykle ważny jest kanał związany $z$ receptorem NMDA. Receptor ten aktywowany jest przez L-glutaminian, główny przekaźnik pobudzajacy. W stanie spoczynkowym kanał jest zablokowany przez jon magnezu. Do jego otwarcia potrzebne jest zarówno przyłączenie się cząsteczki glutaminianu, jak i depolaryzacja błony neuronu wypychajacca $z$ kanału dodatni jon magnezu. Receptor NMDA jest więc detektorem zbierającym informację $z$ dwóch różnych źródeł (detektor koincydencji): o tym czy komórka jest już pobudzona (depolaryzacja) i czy do danej synapsy wydzielony został transmiter pobudzajacy $z$ neuronu presynaptycznego. Indukcja plastyczności w większości połączeń synaptycznych zaczyna się wraz $z$ otwarciem kanałów NMDA, przez które do dendrytów neuronu postsynaptycznego wpływa wapń. Zablokowanie tej transmisji uniemożliwia wywołanie zarówno LTP, jak i LTD. W 1989 r. LISMAN zaproponował model koncepcyjny, w którym wysokie stężenia wapnia prowadzi do indukcji LTP, a średnie - LTD, co zostało później potwierdzone doświadczalnie. YANG i współaut. (1999) pokazali, że krótkotrwałe prądy wapniowe o wysokiej natężeniu, wpływajace do kolca dendrytycznego (wypustki dendrytu, w której znajduje się postsynaptyczna 
część synapsy) wywołuja LTP, a te o niższej amplitudzie i trwajace dłużej - LTD. STDP $z$ kolei opisuje się $z$ biofizycznego punktu widzenia jako układ dwóch detektorów koincydencji. Zwykle rolę detektora wzmocnienia synaptycznego zależnego od synchronizacji (ang. timing-dependent LTP, t-LTP) spełnia receptor NMDA (oraz zależne od napięcia kanały wapniowe). W zależności od połaczenia i rejonu mózgu rolę detektora osłabienia synaptycznego zależnego od synchronizacji (ang. timing-dependent LTD, t-LTD) może spełniać również receptor NMDA; dzieje się tak m.in. w neuronach piramidalnych pola CA1 w hipokampie (NISHIYAMA i współaut. 2000). Rolę detektora t-LTD może też spełniać metabotropowy receptor glutaminergiczny 1 (mGluR1) (znajdujący się m.in. w 2 i 3 warstwie kory czuciowej) (BENDER i współaut. 2006) albo endokannabinoidowy receptor CB1 (CB1R, znajdujący się m.in. w warstwie 5 kory czuciowej) (SJÖSTRÖM i współaut. 2003). Natomiast samo zwiększenie wagi synapsy wiąze się ze wzrostem fosforylacji i insercja nowych receptorów AMPA w błonę synaptyczna, a osłabienie, $z$ ich defosforylacją bądź usuwaniem receptorów AMPA (MALENKa i BeAR 2004).

Jednym $z$ największych wyzwań w modelowaniu mechanizmów molekularnych plastyczności synaptycznej jest fakt, że procesy te obejmuja wiele skal czasowych i przestrzennych. $Z$ tego powodu nie da się skonstruować modeli idealnie odzwierciedlajacych obserwowane zjawiska i dlatego w zależności od typu połaczenia i zadawanego pytania konieczne jest wprowadzenie wielu uproszczeń i poziomów abstrakcji. Same modele biofizyczne można podzielić na dwie kategorie: modele, które skupiają się na dynamice wapnia towarzyszacej indukcji plastyczności, i modele aktywacji szlaków biochemicznych wywołujacych zmiany plastyczne. Pierwsze modele indukcji plastyczności w oparciu o dynamikę przepływu jonów wapnia stosowały system dwóch progów: niższego progu dla wytwarzania LTD i wyższego progu dla LTP. Gdy poziom wapnia w kolcu dendrytycznym znajduje się w przedziale między progami dla wywołania LTD i LTP, następuje osłabienie synaptyczne. Gdy stężenie wapnia przekracza wyższy próg (próg LTP), synapsa ulega wzmocnieniu. Przykładem takich modeli jest model zaproponowany przez SHouvala i współaut. (2002), który poprawnie przewiduje indukcję plastyczności zarówno związana z tetaniczna stymulacja synapsy, jak i paradygmatami wywołujacymi STDP. Immanentna cecha prostych modeli o dwóch progach jest przewidywanie wystapienia LTD dla protokołów doświadczalnych wywołujących LTP o długich ISI (rzędu kilkudziesięciu milise- kund). Dla wielu typów połączeń synaptycznych zjawisko to nie jest obserwowane eksperymentalnie. Tego typu predykcji można uniknać rozszerzajac model $z$ dwoma progami o warunek na minimalną długość czasu, w którym poziom wapnia w kolcu dendrytycznym przekracza próg na LTD (JĘDRZEJEWSKA-SZMEK i współaut. 2017a). Niektóre modele indukcji plastyczności (w układach, w których rolę detektora t-LTD pełnia receptory metabotropowe) uwzględniaja uwalnianie wapnia $z$ magazynów w siateczce śródplazmatycznej (NAKANO i współaut. 2013) i obniżenie prawdopodobieństwa uwolnienia neuroprzekaźnika ze względu na produkcję endokannabinoidów, wywołana aktywacja receptorów metabotropowych sprzężonych $\mathrm{Z}$ białkami Gq (CuI i współaut. 2016).

$\mathrm{W}$ połowie lat 80. XX w. Francis Crick (CRICK 1984), rozważając różne sposoby kodowania wspomnień w synapsach, zasugerował istnienie odpornej na obrót metaboliczny białek „cząsteczki pamięci”, która swoim stanem (aktywnościa) mogłaby kodować informację. Niedługo potem LISMAN (1985) zaproponował kinazę zależna od kalmoduliny i wapnia (ang. Ca2+/calmodulin-dependent protein kinase II, CaMKII), jako swoista pamięć molekularną. Białko to, nieaktywne w swojej formie podstawowej, aktywowane jest przez uwapniona kalmodulinę i dzięki zdolności „autofosforylacji”, pozostaje aktywne nawet po obniżeniu się poziomu wapnia (KATOH i FUJISAWA 1991). Badania eksperymentalne pokazały, że wprowadzenie mutacji typu knock-in, powstrzymujacej autofosforylację CaMKII, uniemożliwia indukcję LTP i powoduje upośledzenie pamięci u myszy (LISMAN i współaut. 2012). Dodatkowo, poziom aktywnej CaMKII silnie zależy od częstości stymulacji wapniem (DE KONINCK i SCHULMAN 1998), im wyższa jest ta częstość, tym większa jest ilość aktywnej kinazy, co wiąże się $z$ obserwacjami eksperymentalnymi, że stymulacja tetaniczna o wysokiej częstości wywołuje LTP, a stymulacja tetaniczna o niższej częstości wywołuje LTD. Z kolei uważa się, że za LTD odpowiada aktywacja fosfataz, w szczególności fosfatazy białkowej 1 (ang. protein phosphatase 1, PP1), 2A (PP2A) i 2B (PP2B, zwanej także kalcyneuryna) (MALENKA i BEAR 2004).

Pierwsze modele mechanizmów biochemicznych w plastyczności synaptycznej bazowały na aktywacji CaMKII i fosfataz. Począwszy od modelu LisMAN A (1989), konstruowano je w oparciu o bistabilne zachowanie CaMKII, gdzie interakcje pomiędzy CaMKII a fosfatazami (kalcyneuryna i PP1) (PI i LISMAN 2008; GRAUPNER i BRUNEL 2007, 2012) stanowiły przełącznik między LTP a LTD. Modele te także poprawnie przewiduja 
indukcję plastyczności zarówno zwiąanej z tetaniczna stymulacja synapsy, jak i paradygmatami wywołujaccymi STDP. Na szczególną uwagę zasługuje model CASTELLANIEGO i współaut. (2005), którzy skupili się na opisie tego, jak indukcja LTP i LTD wpływa na fosforylację receptora AMPA, pokazujacc, że małe zmiany poziomu wapnia powoduja defosforylację receptora AMPA i, w konsekwencji, LTD, a duże zwiększaja liczbę ufosforylowanych receptorów i powoduja LTP.

Oddzielna gałąz modeli CaMKII skupia się na odwzorowaniu niezwykle skomplikowanego procesu aktywacji CaMKII przez kalmodulinę, a także zrozumieniu i przewidywaniu zależności aktywacji CaMKII od częstości oscylacji bodźca wapniowego (ROMANO i współaut. 2017) oraz tego, jak współzawodnictwo o kalmodulinę między CaMKII innymi białkami przez nia aktywowanymi, takimi jak kalcyneuryna, może wpływać na indukcję plastyczności.

Badania eksperymentalne pokazuja, że CaMKII nie jest jedynym zwiazkiem kluczowym dla plastyczności synaptycznej i sugeruja, że także inne zwiazki odgrywaja w niej rolę, np. kinaza białkowa A (PKA). Wpływ substancji neuromodulujących, takich jak dopamina czy acetylocholina, stochastyczność zjawisk zachodzacych w kolcach synaptycznych i nieodmiennie towarzyszacy procesom biologicznym szum, lokalizacja czassteczek, a także rozkład przestrzenny stymulowanych kolców, moga mieć kluczowy wpływ na aktywacje biochemicznych składowych plastyczności synaptycznej. Pionierski model szlaków sygnalizacyjnych w plastyczności synaptycznej zaproponowany przez BHALLE i IYENGARA (1999), wykraczał poza proste interakcje między CaMKII a fosfatazami, uwzględniajac m.in. aktywację czterech szlaków sygnałowych prowadzacych do aktywacji kinaz aktywowanych mitogenami (ang. mitogen-activated protein kinases, MAPK). Model ten pokazał, że w pewnych warunkach krótkotrwałe zwiększenie poziomu wapnia może prowadzić do aktywacji CaMKII przekraczającej 20 minut, a także, że wielość sygnałów wyjściowych sieci szlaków biochemicznych może być swoistym zaworem bezpieczeństwa gwarantującym, że tylko niektóre sygnały przekładaja się na zmiany behawioru.

Aktywacja MAPK wydaje się być jednym $z$ procesów łączących różne formy plastyczności (SwEatT 2001). Co więcej, badania eksperymentalne sugeruja, że MAPK graja rolę integratorów sygnałów biochemicznych i detektorów koincydencji, które koordynuja odpowiedź na sygnały płynace spoza komórki. $Z$ tego powodu część modeli biochemicznych skupia się na aktywacji MAPK (AJAY i BHALla 2007, NEVEs i współaut. 2008, BHALLA 2017). AJAY i BHALLA (2007) wykazali, że bez dodatkowego sprzężenia zwrotnego między aktywacja MAPK a wapniem wpływającym do dendrytu, dyfuzja aktywnego MAPK jest zbyt wolna, by obejmowała odcinki dendrytu o długości przekraczajacej $100 \mu \mathrm{m}$, co obserwuje się doświadczalnie. Z kolei NEVES i współaut. (2008) pokazali, że kształt dendrytu i stężenie fosfodiesteraz, związków degradujących cykliczny adenozynomonofosforan (cAMP), wtórny przekaźnik grający ważna rolę $\mathrm{w}$ plastyczności synaptycznej aktywujacy szereg szlaków sygnałowych, które zbiegaja się aktywując MAPK i kontrolujac ich gradient przestrzenny. Niski poziom diesteraz pozwalał na dyfuzje cAMP i w konsekwencji małe różnice przestrzenne w aktywacji MAPK. Niedawno BHALLA (2017), używajac deterministycznego modelu aktywacji szlaków sygnałowych pokazał, że skoordynowana stymulacja kolców dendrytycznych zwiększa aktywację MAPK.

Powyższe modele opierały się na symulacji układu reakcji biochemicznych za pomocą równań kinetycznych opisujących zmiany stężeń zwiąków chemicznych. Zastosowanie opisu tego typu wymaga spełnienia kil$\mathrm{ku}$ warunków, m.in. odpowiednio wysokiej liczebności populacji każdego ze związków chemicznych w układzie, a także jego jednorodności (zwiazki chemiczne musza być ze soba „dobrze wymieszane”). Kolce dendrytyczne sa małymi strukturami, o objętości od 0,01 do $0,8 \mu^{3}$, i ze względu na ich małe rozmiary, nawet wysokie stężenia zwiazków chemicznych (jak na warunki komórkowe) wewnatrz kolca wiaża się $z$ występowaniem w nim niewielkiej liczby czassteczek. Sam kolec dendrytyczny nie jest również jednorodny; zwiazki chemiczne maja swoja specyficzna lokalizację, np. sa zadokowane w błonie. W takich przypadkach poprawnym podejściem do modelowania szlaków sygnałowych jest użycie metod stochastycznych (GILLESPIE 1977, ANDREWS i BRAY 2004), przy jednoczesnym uwzględnieniu morfologii symulowanego układu i lokalizacji czasteczek. Szczególna rola, która graja w plastyczności fluktuacje stochastycznie, jest uwidoczniona przez wyniki badań ANTUNes i De SCHUTTERA (2012), którzy wykazali, że dla małych populacji (< 50 cząsteczek) zwiąków uczestniczacych $\mathrm{w}$ transdukcji sygnału, dla tego samego typu pobudzenia, synapsa $z$ pewnym prawdopodobieństwem przełącza się między stanami „brak plastyczności” i „pobudzenie”, co powoduje zatarcie progu plastyczności i pozwala na wiele różnych stabilnych poziomów osłabienia. Efekt ten zależy od liczebności zaangażowanej populacji molekularnej: 
im większa populacja, tym wyraźniejszy staje się próg wywołania plastyczności.

Uwzględnienie morfologii układu, czyli kolca dendrytycznego i dendrytu, w modelach biochemicznych pozwala na lepsze zrozumienie roli pełnionej $\mathrm{w}$ indukcji plastyczności synaptycznej przez neuromodulatory, a także inne związi chemiczne takie jak PKA, których waga wskazywana była w doświadczeniach neurobiologicznych, a także niedawno odkrytych zwiazków takich jak wymieniacze cGMP zależne od cAMP (ang. exchange protein activated by cAMP, epac) (DE RoOIJ i współaut. 1998), których rola nie jest jeszcze jasna. Jako przykład może tu służyć model indukcji plastyczności terminali kolaterali Schaffera (JE_DRZEJEWSKA-SzMEK i współaut. 2017b), który pokazał w oparciu o dynamikę CaMKII, PKA i epaka, że można przewidywać indukcje wzmocnienia synaptycznego trwającego dłużej niż $2 \mathrm{~h}$ (ang. late phase LTP, 1-LTP) oraz że w tego typu plastyczności kluczowa rolę może grać aktywacja receptora beta-adrenergicznego. 1-LTP wymaga syntezy nowych białek i specjalnego, biochemicznego oznaczenia stymulowanego kolca synaptycznego (ang. synaptic tagging and capture, STC) (FREY i MORRIS 1997). Podobnie model plastyczności w połaczeniach kortykostriatalnych pozwala na przewidywanie kierunku plastyczności synaptycznej w oparciu o aktywacje kinaz (m.in. CaMKII, PKA) i endokannabinoidów (BLACKWELL i współaut. 2019).

Modele plastyczności synaptycznej otworzyły droge do wstępnego wyjaśnienia biofizycznych i biochemicznych procesów sterujacych uczeniem i formowaniem się pamięci. Aby je lepiej zrozumieć musimy konstruować lepsze modele kontroli syntezy białek, zmian morfologii kolca dendrytycznego towarzyszących plastyczności synaptycznej, a także przestrzennych aspektów transdukcji sygnału w kolcu dendrytycznym i dendrycie oraz interakcji i tworzenia się bezbłonowych organelli, takich jak gęstość postsynaptyczna.

\section{PODSUMOWANIE}

Systematycznie rosnaca precyzja pomiarów neurobiologicznych, wysokoprzepustowe techniki pozwalajace na zbieranie masywnych danych charakteryzujacych układ nerwowy, zarówno jego budowę, jak i funkcje, na wszystkich poziomach, od subkomórkowego po zachowanie, zmusza nas do rozwoju metod i narzędzi pozwalajacych na metodyczna i konsekwentna integrację zbieranych danych. Na poziomie najbardziej podstawowym, to bazy danych i serwisy internetowe pozwalajace na przechowywanie i udostępnianie wyników doświadczeń. Na wyższym poziomie to modele, które w naturalny sposób abstrahują od specyfiki poszczególnych doświadczeń i stanowią naturalne schematy integrujace wiedzę. Neuroinformatyka jest źródłem tych podstaw obliczeniowych i teoretycznych dla badań nad mózgiem, bez których obecnie rozwój nauki jest bardzo trudny, jeśli nie niemożliwy.

\section{Streszczenie}

Neuroinformatyka to młoda dziedzina na pograniczu informatyki, biologii, chemii, fizyki i medycyny, obejmujacca wszelkie zastosowania nauk ścisłych w neurobiologii, w tym neurobiologie teoretyczna, obliczeniowa, analizę sygnałów neurobiologicznych, rozwój wszelkich metod analizy danych uzyskanych $\mathrm{w}$ ramach badań mózgu i behawioru oraz ich zastosowanie. W artykule omawiamy pokrótce genezę i rozwój neuroinformatyki. Następnie skupiamy się na jednej $z$ gałęzi neuroinformatyki, neurobiologii obliczeniowej, czyli modelowaniu układu nerwowego. Wreszcie dokładniej przyglądamy się problemowi modelowania plastyczności synaptycznej w mózgu.

\section{LITERATURA}

AJAY S., BHALla U., 2007. A propagating ERKII switch forms zones of elevated dendritic activation correlated with plasticity. HFSP J. 1, 49-66.

ANDREWS S. S., BRAY D., 2004. Stochastic simulation of chemical reactions with spatial resolution and single molecule detail. Phys. Biol. $1,137-151$.

Antunes G., DE SchutTer E., 2012. A stochastic signaling network mediates the probabilistic induction of cerebellar long-term depression. J. Neurosci. 32, 9288-300.

Bender V. A., Bender K. J., BRASIER D. J., FElDMAN D. E., 2006. Two coincidence detectors for spike timing-dependent plasticity in somatosensory cortex. J. Neurosci. 26, 4166-4177.

BI G. Q., POO M. M., 1998. Synaptic modifications in cultured Hippocampal neurons: dependence on spike timing, synaptic strength, and postsynaptic cell type. J Neurosci 18, 1046410472.

Bienestock E. L., CoOper L. N., MunRo P. W., 1982. Theory for the development of neuron selectivity: orientation specificity and binocular interaction in visual cortex. J. Neurosci. 2, 3248.

BHAlla U. S., 2017. Synaptic input sequence discrimination on behavioral timescales

mediated by reaction-diffusion chemistry in dendrites. eLife 6, e25827.

BHALLA U. S., IYENGAR R., 1999. Emergent properties of networks of biological signaling pathways. Science 283, 381-387.

BIALEK W., BOTSTEIN D., 2004. Introductory science and mathematics education for 21st-Century biologists. Science 303, 788-790.

Blackwell K. T., Salinas A. G., Tewatia P., ENGLish B., HellgRen KotalesKi J., LOVINGER D. M., 2019. Molecular mechanisms underlying striatal synaptic plasticity: relevance to chronic alcohol consumption and seeking. Eur J Neurosci. 49, 768-783.

Blais B., CoOper L. N., Shouval H., 2000. Formation of direction selectivity in natural scene environments. Proc. Natl. Acad. Sci. USA 12, 5. 
CASTEllani G., QUiNLAN E., BERSANI F., COOPER L., Shouval H., 2005. A model of bidirectional synaptic plasticity: from signaling network to channel conductance. Learn. Mem. 12, 42332.

Clopath C., Büsing L., Vasilaki E., Gerstner W. 2010. Connectivity reflects coding: a model of voltage-based STDP with homeostasis. Nat. Neurosci. 13, 344.

COHEN J. E., 2004. Mathematics is biology's next microscope, only better; biology is mathematics' next physics, only better. PLoS Biology. $2, \mathrm{e} 439$

CRICK F., 1984. Neurobiology: Memory and molecular turnover. Nature 312, 101.

Cui Y., PROKIN I., Xu H., DelORD B., Genet S. VENANCE L., BERRY H., 2016. Endocannabinoid dynamics gate spike-timing dependent depression and potentiation. eLife 5, e13185.

DE KonINCK P., Schulman H., 1998. Sensitivity of CaM kinase II to the frequency of $\mathrm{Ca} 2+$ oscillations. Science 279, 227-230.

DE ROOIJ J., ZWARTKRUiS F. J. T., VERHEIJEN M. H. G., CoOl R. H., NiJman S. M. B., WitTinGHOFER A., BOS J. L., 1998. Epac is a Rap1 guanine-nucleotide-exchange factor directly activated by cyclic AMP. Nature 396, 474-477.

DENKER M., EINEVOLL G., FRANKE F., GRÜN S. Hagen E., KerR J., Nawrot M., Ness T. B., RITZ R., SMiTh L., WACHTLER T., WÓJCIK D. K., 2014. Report from the 1st INCF Workshop on Validation of Analysis Methods, INCF; http:// archive.incf.org/documents/documents/workshop-reports /incf-workshop-on-validation-of-analysis-methods/at_download/2013_validation_report_interative.pdf.

FREY U., MORRIS R. G., 1997. Synaptic tagging and long-term potentiation. Nature 385, 533536.

Gerstner W., Kistler W. M., NAUd R., PANinski L., 2014. Neuronal Dynamics. From Single Neurons to Networks and Models of Cognition. Cambridge Univ. Press., Cambridge.

GILLESPIE D. T., 1977. Exact stochastic simulation of coupled chemical reactions. J. Phys. Chem. 81, 2340-2361.

Goodfellow I., Bengio Y., Courville A., 2016. Deep Learning. MIT Press.

GRAUPNER M., BRUNEL N., 2007. STDP in a bistable synapse model based on CaMKII and associated signaling pathways. PLoS Comput. Biol. 3, e221.

GRAUPNER M., BRUNEL N., 2012. Calcium-based plasticity model explains sensitivity of synaptic changes to spike pattern, rate, and dendritic location. Proc. Natl. Acad. Sci. USA 109, 3991-3996.

Halnes G., Ostby I., Pettersen K. H., OMholt S. W., Einevoll G. T., 2013. Electrodiffusive model for astrocytic and neuronal ion concentration dynamics. PLoS Computat. Biol. 9, e1003386.

HeBB D. O., 1949. The Organization of Behavior. Wiley \& Sons, New York.

HodGKIN A. L., HuXleY A. F., 1952. A quantitative description of membrane current and its application to conduction and excitation in nerue. J. Physiol. 117, 500-544.

Hubel D. H., WiEsel T. N., 1962. Receptive fields, binocular interaction and functional architecture in the cat's striate cortex. J .Physiol. 160, 106-154.

JACK J. J. B., NOBLE D., TSIEN R. W., 1975. Electric current flow in excitable cells. Clarendon Press, Oxford.
JEDRZEJEWSKA-SZMEK J., DAMODARAN S., DORMAN D. B., BlaCKWEll K. T., 2017a. Calcium dynamics predict direction of synaptic plasticity in striatal spiny projection neurons. Eur. J. Neurosci. 45, 1044-1056.

JEDRZEJEWSKA-SZMEK J., LUCZAK V., ABEL T., BLACKWELL K. T., 2017b. $\beta$-adrenergic signaling broadly contributes to LTP induction. PLOS Comput Biol 13, e1005657.

JOHNSTON D., WU S. M., 1995. Foundations of Cellular Neurophysiology. MIT Press, Cambridge.

KAMIŃSKI J., Sullivan S., ChUng J. M., Ross I. B., MamelaK A. N., RUTishauser U., 2017. Persistently active neurons in human medial frontal and medial temporal lobe support working memory. Nat. Neurosci. 20, 590-601.

KATOH T., FUJISAWA H., 1991. Autoactivation of calmodulin-dependent protein kinase II by autophosphorylation. J. Biol. Chem. 266, 30393044.

KocH C., 1999. Biophysics of Computation. Oxford University Press: New York, New York.

KONORSKI J., 1948. Conditioned Reflexes and Neuron Organization. Cambridge University Press, Cambridge.

LISMAN J., 1985. A mechanism for memory storage insensitive to molecular turnover: A bistable autophosphorylating kinase. Proc. Natl. Acad. Sci. USA 82, 3055-3057.

LISMAN J., 1989. A mechanism for the Hebb and the anti-Hebb processes underlying learning and memory. Proc Natl Acad Sci USA 86, 9574-9578.

LiSMAN J. E., YASUdA R., RAghaVACHARI S., 2012. Mechanisms of CaMKII action in long-term potentiation. Nat Rev Neurosci. 13, 169-182.

MALENKA R. C., BEAR M. F., 2004. Receptor trafficking and synaptic plasticity. Neuron 44, 5-21.

MARKRAM H., LuBKe J., FROTSChER M., SAKMANN B., 1997. Regulation of synaptic efficacy by coincidence of postsynaptic APs and EPSPS. Science 275, 213-215.

NABAVI S., FOX R., PROULX C., LIN J. Y, TSIEN R. Y., MALINOW R., 2014. Engineering a memory with LTD and LTP. Nature 511, 348-352.

NAKANO T., Yoshimoto J., DOYA K., 2013. A model-based prediction of the calcium responses in the striatal synaptic spines depending on the timing of cortical and dopaminergic in puts and post-synaptic spikes. Front. Comput. Neurosci. 7, 119.

Neves S. R., Tsokas P., Sarkar A., Grace E. A., RANGAMANI P., TAUBENFELD S. M., AlBERINI C. M., SCHAFF J. C., Blitzer R. D., MORARU I. I., IYENGAR R., 2008. Cell shape and negative links in regulatory motifs together control spatial information flow in signaling networks. Cell 133, 666-680.

Nishiyama M., Hong K., Mikoshiba K., Poo M.-M., KATO K., 2000. Calcium stores regulate the polarity and input specificity of synaptic modification. Nature 408, 584-588.

OSCHMANN F., BERRY H., OBERMAYER K., LENK K., 2018. From in silico astrocyte cell models to neuron-astrocyte network models: A review. Brain Res. Bull. 136, 76-84.

PECHURA C. M., MARTIN J. B., 1991. Mapping the Brain and Its Functions: Integrating Enabling Technologies into Neuroscience Research (Consensus study report). Washington DC: National Academy Press., doi:10.17226/1816.

PI H. J., LISMAN J. E., 2008. Coupled phosphatase and kinase switches produce the tristability required for long-term potentiation and 
long-term depression. J. Neurosci. 28, 1313213138.

Quiroga R. Q., Reddy L., Kreiman G., Koch C., FRIED I., 2005. Invariant visual representation by single neurons in the human brain. Nature 435, 1102-1107.

Romano D. R., PharRis M. C., PATEl N.M., KinZER-URSEM T. L., 2017. Competitive tuning :competition's role in setting the frequency-dependence of $\mathrm{Ca} 2+$-dependent proteins. PLoS Comput. Biol. 13, e1005820.

SHOUVAL H., INTRATOR N., LAW C. C., COOPER L. N., 1996. Effect of binocular cortical misalignment on ocular dominance and orientation selectivity. Neural Comput. 8, 1021-1040.

Shouval H. Z., BeAR M. F., COOPER L. N., 2002. A unified theory of NMDA receptor-dependent bidirectional synaptic plasticity. Proc. Natl. Acad. Sci. USA 99, 10831-10836.

SJÖSTRÖM P. J., TuRRIGIANO G. G., NELSON S. B., 2003. Neocortical LTD via coincident activation of presynaptic NMDA and cannabinoid receptors. Neuron 39, 641-654.
SWEATT J. D., 2001. The neuronal MAP kinase cascade: a biochemical signal integration system subserving synaptic plasticity and memory. J. Neurochem. 76, 1-10.

TUCKWELL H. C., 1988. Introduction to theoretical neurobiology. Cambridge University Press

WILSON H. R., COWAN J. D., 1972. Excitatory and inhibitory interactions in localized populations of model neurons. Biophys. J. 12, 1-24.

TURRIGANO G. G., 1999. Homeostatic plasticity in neuronal networks: the more things change, the more they stay the same. Trend Neurosci. 22, 221-227.

YANG S.-N., TANG Y.-G., ZUCKER R., 1999. Selective induction of LTP and LTD by postsynaptic [Ca2+]i elevation. J. Neurophysiol. 81, 781787.

Yeung L. C., Shouval H. Z., Blais B. S., CoOper L. N., 2004. Synaptic homeostasis and input selectivity follow from a calcium-dependent plasticity model. Proc. Natl. Acad. Sci. USA 101, 14943-14948.

KOSMOS Vol. 69, 1, 157-167, 2020

\section{JoANNA JĘDRZEJEWSKA-SZMEK ${ }^{1}$, DANIEL K. WÓJCIK ${ }^{1,2}$}

${ }^{1}$ Laboratory of Neuroinformatics, Nencki Institute of Experimental Biology PAS, 3 Pasteur Str., 02-093 Warszawa, ${ }^{2}$ Institute of Applied Psychology, Faculty of Management and Social Communication, Jagiellonian University, 4 Łojasiewicza Str., $30-348$ Kraków, E-mail: d.wojcik@nencki.edu.pl

\section{FACETS OF NEUROINFORMATICS}

\section{Summary}

Neuroinformatics is a young field on the border between computer science, biology, chemistry, physics, and medicine, encompassing all applications of sciences in neurobiology, including theoretical and computational neuroscience, analysis of neurobiological signals, development of all methods of analysis of data obtained in the study of the brain and behavior, and their applications. Here we present briefly the history of neuroinformatics and the stimuli for its development. Then, we focus on one branch of neuroinformatics: computational neuroscience, that is modeling of the nervous system. We then look closer at the problem of modeling of synaptic plasticity in the brain. 